\title{
Triassic marine reptiles and other fossil vertebrates from the area of Godech, Western Bulgaria
}

\section{Триаски морски влечуги и други фосилни гръбначни от района на Годеч, Западна България}

\author{
Vladimir Nikolov', Docho Dochev², Lubomir Metodiev³, Dimitar Dimitrov ${ }^{4}$, Gergana Velyanova', \\ Latinka Hristova ${ }^{1}$ \\ Владимир Николов', Дочо Дочев 2 , Любомир Методиев ${ }^{3}$, Димитьр Димитров \\ Гергана Велянова ${ }^{2}$, Латинка Христова ${ }^{1}$
}

\begin{abstract}
${ }^{1}$ National Museum of Natural History, Bulgarian Academy of Sciences, 1, Tzar Osvoboditel Blvd., 1000 Sofia; E-mails: vlado_raptor@mail.bg; latihristova@abv.bg

${ }^{2}$ Sofia University "St. Kliment Ohridski”, Department of Geology, Paleontology and Fossil Fuels, 15, Tsar Osvoboditel Blvd., 1504 Sofia; E-mails: dochev@gea.uni-sofia.bg; gergana315@gmail.com

${ }^{3}$ Geological Institute, Bulgarian Academy of Sciences, Acad. G. Bonchev str., bl. 24, 1113 Sofia; E-mail: lubo@geology.bas.bg

${ }^{4}$ Independent researcher; E-mail: dimitrow.dimitar@gmail.com
\end{abstract}

\begin{abstract}
Hitherto, the popular understanding was that the Bulgarian fossil record of Mesozoic tetrapods (four-limbed vertebrates) has been restricted to the Upper Cretaceous. In this contribution we report on the discovery of isolated bones of marine reptiles and teeth of various vertebrates from the Middle Triassic carbonate rocks outcropping near the town of Godech, Western Bulgaria. A revision of the currently held orthodoxy that Bulgaria is mostly a barren land when it comes to Mesozoic tetrapods is urged.
\end{abstract}

Keywords: Middle Triassic, Sauropterygia, marine reptiles, Mogila-Babintsi Formation, Godech.

Historically, the fossil record of Mesozoic reptiles in Bulgaria has been generally scarce (Boev, 2017). Although it has expanded in the past two decades, all well documented occurrences and taxonomically identified specimens are restricted mainly to Upper Cretaceous strata (Nikolov, Westphal, 1976; Jagt et al., 2006; Godefroit, Motchurova-Dekova, 2010; Mateus et al., 2010; Nikolov et al., 2020). Some poorly known specimens extend the fossil record further back in time (Bakalov, Filkov, 1954; Rieppel, Wild, 1996). Except for a single specimen of Nothosaurus giganteus (Rieppel, Wild, 1996), no other Triassic reptiles have been reported from Bulgaria to date.

Herein we report Middle Triassic vertebrate remains, including marine reptiles, from the area of the town of Godech, Western Bulgaria (Fig. 1). The reptile fossils were discovered by Dimitar Dimitrov, a local amateur collector, who, understanding their scientific value, contacted the paleontologists at the National Museum of Natural History - BAS. Two field trips to the area northeast of Godech took place in the summer of 2021. During these trips we collected fossil teeth and a poorly preserved rib (Fig. 1b-e). A few other fragments were observed in situ but not extracted. Two localities within the prospected area yielded vertebrate material. These fossil-bearing sites take part of a relatively wide strip of exposures of W-E trend, which crops out close to the north of Godech, and which is entirely composed of thick Middle Triassic (Anisian) carbonates (Fig. 1a). Stratigraphically, the rocks of this strip represent undivided succession, referred to as Mogila-Babintsi Formation (Angelov et al., 2008), which is made up of various limestones and less of marlstones and dolostones. In a narrow geological context, the strip takes the inner part of the Vidlich imbricate thrust-sheet that is deformed into several 
local-scale folds (ibid.). In a regional geological context, the Vidlich sheet is developed along the Vidlich dislocation, which is a prominent late Alpine structure that divides the West Balkan and the Sredna Gora tectonic zones (sensu Ivanov, 2017) in Eastern Serbia and Western Bulgaria.

The observed Middle Triassic fossil fauna includes (mostly teeth of) chondrichthyans, osteichthyans, and sauropterygians (possibly placodonts and nothosauroids). Of these, most interesting, due to their rareness, are the marine reptiles. Regrettably, the most impressive reptile fossils (Fig. 1f-i) are not available for study, because, at least for now, they are not deposited in a public paleontological collection. The vertebrate fossils are dark brown to black in color. The majority of them were collected on the bedding surfaces of various carbonate rocks, usually nodular limestones. Fossils are partly entombed in a silty to sandy matrix, thus easily noticed in the field. Said matrix is characterized by the occasional presence of mica flakes.

The Early Triassic saw life recovering from the largest biotic crisis of the Phanerozoic eon (Chen, Benton, 2012). In the sea, the clade Sauropterygia underwent quick adaptive radiation giving rise to placodonts, pachypleurosaurs, nothosaurs, and pistosauroids (of which plesiosaurs evolved) (Sues, 2019). These marine reptiles enjoyed wide distribution within the Tethyan Realm (Bardet et al., 2014) and experienced highest phenotypic and ecological diversity (disparity) during the Middle and Late Triassic (Stubbs, Benton, 2016). Given the lithological and facial similarities between the Middle to Upper Triassic sedimentary successions in Bulgaria and those in Central and Western Europe where sauropterygian fossils are common, the apparent absence of marine reptiles in the Bulgarian fossil record has been puzzling. By coming from geologically, stratigraphically, and sedimentologically well studied region, the fossil material from Godech suggests that the currently non-existent Triassic tetrapod record is result either of overlooking during field work caused by time or budgetary constraints, or due to lack of interest in these fossil animals, because of their low stratigraphic value.

The discovery of marine reptiles in the Middle Triassic carbonates near Godech illustrates the role that non-professionals have in the vertebrate pale-

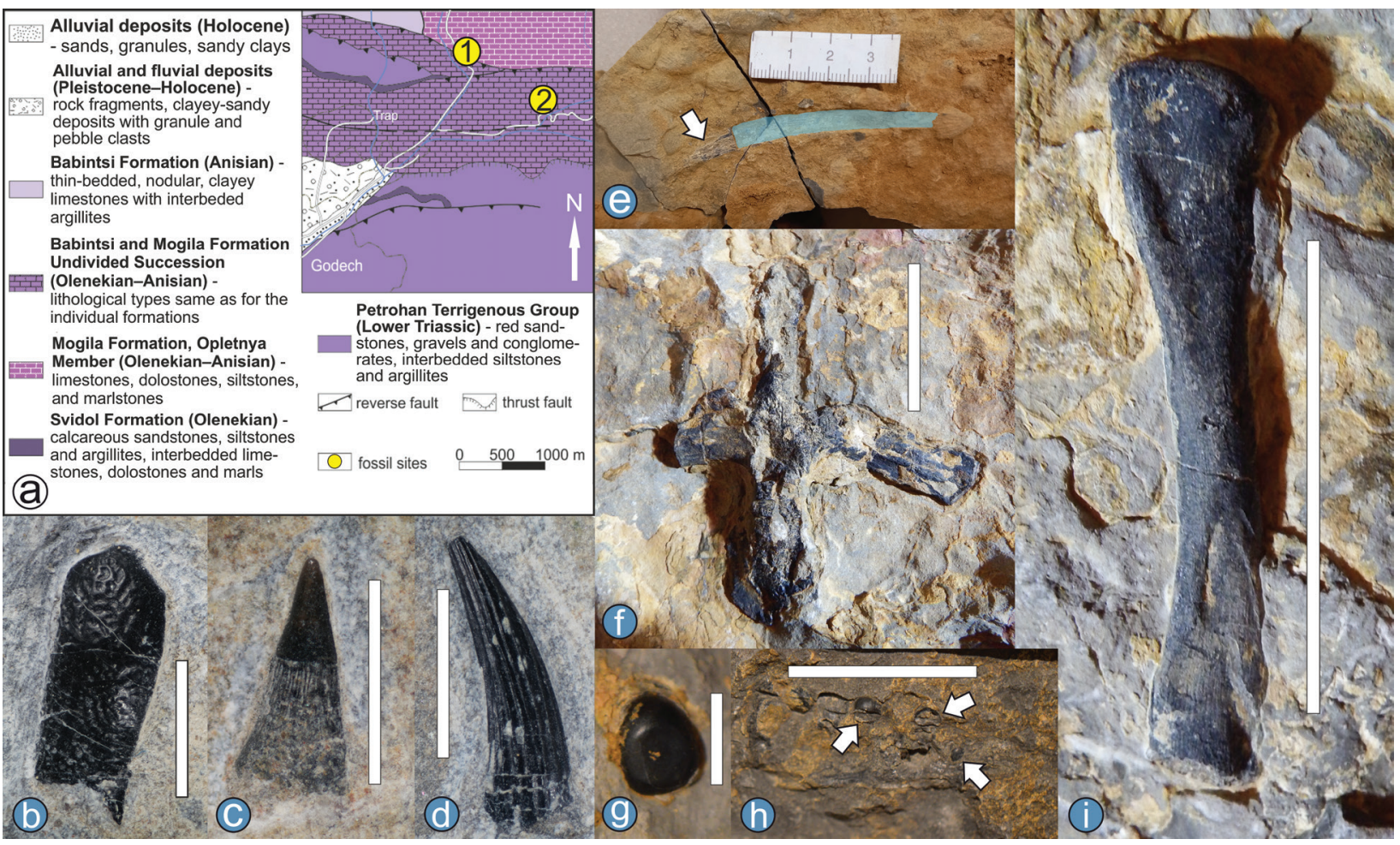

Fig. 1. Vertebrate fossils from the area of Godech, Western Bulgaria. $a$, geological map of the area northeast of Godech (after Angelov et al., 2008) with the position of the fossil sites; $b$, a chondrichthyan tooth; $c$, an osteichthyan tooth - ?Saurichthys; $d$, a nothosaur tooth; $e$, poorly preserved and partly enclosed by rock matrix sauropterygian rib (arrow), with adjacent imprint left by the eroded bone (transparent-blue area); $f$, a sauropterygian vertebra; $g$, a placodont-type tooth; $h$, a poorly preserved jaw with few in situ placodont-type teeth (arrows); $i$, a sauropterygian femur. The various teeth $(b-d)$ are collected from fossil site 1 , while the postcranial elements and one tooth $(e-i)$ are collected from fossil site 2 . Scale bars: $b-d-2 \mathrm{~mm} ; f, h, i-3 \mathrm{~cm} ; g-5 \mathrm{~mm}$. 
ontology of Mesozoic tetrapods in Bulgaria (Mateus et al., 2010; Nikolov et al., 2020) and brings attention to the dangers of losing scientifically important specimens to private collections. Furthermore, it forces us to rethink the nature of the Bulgarian fossil record of Mesozoic tetrapods - it is now clear that fossils of Mesozoic tetrapods are not as rare as once thought and that such finds should not be considered an extraordinary, or unlikely events. If chances of important vertebrate fossils ending up in scientific collections are to be improved, then the local scientific community needs to embrace the idea of tetrapod fossils of Mesozoic age being relatively common. Thus, we encourage colleagues to intentionally look for and collect vertebrate fossils when conducting work in terrains dominated by Mesozoic sedimentary rocks, regardless of the lithological or facial characteristics of the sediments.

Acknowledgements: This work is contribution to project КП-06ПН44/16, 2020, funded by the Bulgarian National Science Fund. V. Nikolov is supported by the Karoll Knowledge Foundation. We thank Dr B. Zlatkov (IBER-BAS) for preparing some of the microphotographs used here.

\section{References}

Angelov, V., G. Aidanlijsky, P. Petrov, S. Gerdzhikov, M. Antonov, H. Kiselinov, V. Valev. 2008. Explanatory Notes to the Geologic Map of Bulgaria in Scale 1:50 000, Map Sheet K-34-35-V (Godech). Sofia, Ministry of Environment and Water, Bulgarian Geological Survey, 66 p.

Bakalov, P., L. Filkov. 1954. Remains of reptiles (Reptilia) from the Upper Jurassic in Northwestern Bulgaria. - Priroda, 3, 75-76 (in Bulgarian).

Bardet, N., J. Falconnet, V. Fischer, A. Houssaye, S. Jouve, X. Pereda Suberbiola, A. Pérez-García, J.-C. Rage, P. Vincent. 2014. Mesozoic marine reptile palaeobiogeography in re- sponse to drifting plates. - Gondwana Res., 26, 869-887; http://doi.org/10.1016/j.gr.2014.05.005.

Boev, Z. 2017. Fossil and subfossil records of Reptiles (Reptilia Laurenti, 1768) in Bulgaria. - Historia Naturalis Bulgarica, 24, 165-178; https://doi.org/10.5281/zenodo.4043967.

Chen, Z.-Q., M. Benton. 2012. The timing and pattern of biotic recovery following the end-Permian mass extinction. Nature Geoscience, 5, 375-383; https://doi.org/10.1038/ NGEO1475.

Godefroit, P., N. Motchurova-Dekova. 2010. Latest Cretaceous hadrosauriod (Dinosauria: Ornithopoda) remains from Bulgaria. - Comptes Rendus Palevol, 9, 163-169; https://doi. org/10.1016/j.crpv.2010.05.003.

Ivanov, Ž. 2017. Tectonics of Bulgaria. Sofia University Press, 331 p. (in Bulgarian with English abstract).

Jagt, J. W. M., N. Motchurova-Dekova, P. Ivanov, H. Cappetta, A. S. Schulp. 2006. Latest Cretaceous mosasaurs and lamniform sharks from Labirinta cave, Vratsa district (northwest Bulgaria): a preliminary note. - Annales Géologiques de la Péninsule Balkanique, 67, 51-63; https://doi.org/10.2298/ gabp0667051j.

Mateus, O., G. J. Dyke, N. Motchurova-Dekova, G. D. Kamenov, P. Ivanov. 2010. The first record of a dinosaur from Bulgaria. - Lethaia, 43, 88-94; https://doi.org/10.1111/ j.1502-3931.2009.00174.x.

Nikolov, I., F. Westphal. 1976. Mosasaurier-Funde aus der Oberkreide von Nordwest-Bulgarien. - Neues Jahrbuch für Geologia und Paläontologie, Monatshefte, 10, 608613.

Nikolov, V., D. Dochev, P. Pavlishina, S. Brusatte, M. Yaneva, R. Konyovska, V. Vergilov, N. Simov, N. Spassov, L. Hristova. 2020. Welcome to "Cretaceous Park": Three years of research at the Late Cretaceous tetrapod fossil site near the town of Tran, Western Srednogorie. - Rev. Bulg. Geol. Soc., 81, 3, 141-143.

Rieppel, O., R. Wild. 1996. A revision of the genus Nothosaurus (Reptilia: Sauropterygia) from the Germanic Triassic, with comments on the status of Conchiosaurus clavatus. Fieldiana: Geology, new series, 34, 1-82.

Stubbs, T., M. Benton. 2016. Ecomorphological diversification of Mesozoic marine reptiles: the roles of ecological opportunity and extinction. - Paleobiology, 42, 547-573; https:// doi.org/ 10.1017/pab.2016.15.

Sues, H.-D. 2019. The Rise of Reptiles: 320 Million Years of Evolution. Johns Hopkins University Press, 400 p. 